\title{
The Moderating Role of Workers' Union Activities on the Relationship between Employee Wellness Programs and Medical Employee Output at Kenyatta National Hospital (KNH), Kenya
}

\author{
Ruth Kanini Bosire ${ }^{1 *}$, Dr. James Muya $\mathrm{PhD}^{2}$, Daisy Matula, $\mathrm{PhD}^{3}$
}

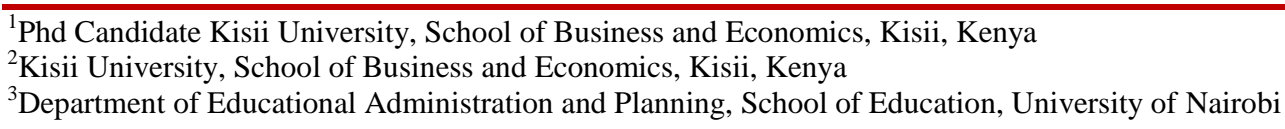

*Corresponding author: Ruth Kanini Bosire

The main purpose for this study was to determine the influence of moderating effect of workers 'union activities on the relationship between wellness programs and medical employees output at Kenyatta National Hospital (KNH) as anchored on Herzberg two factor theories. Explanatory research design was adopted in pragmatism approach. Data was collected using close-ended questionnaire from a sample of 328 medical staff derived from a target population of 2175 medical staff. Hypotheses were tested using linear regression for direct effect while hierarchical regression was used to test interaction effect. The findings indicated that wellness programs had a positive and significant relationship with employee output at KNH. It was also established that workers' union activities significantly moderate the relationship between wellness programs and employee output among medical employees at KNH. The study concluded that employee wellness programs enhance employee output in hospitals. In addition, under high level of workers' union activities, employee wellness programs had a positive and significant relationship with employee output at KNH. The study recommends that Hospitals need to fully embrace employee wellness programs due to its benefits to the human resource pool.

Keywords: Workers' Union Activities, Wellness Programs, Employees Output, Hospital.

Copyright $(\odot) 2021$ The Author(s): This is an open-access article distributed under the terms of the Creative Commons Attribution 4.0 International License (CC BY-NC 4.0) which permits unrestricted use, distribution, and reproduction in any medium for non-commercial use provided the original author and source are credited.

\section{INTRODUCTION}

\section{Background to the Study}

Employee output refers to a performance management system that focalises on employee outcomes at work underlining both quantitative and qualitative concerns. This output may consist of: commitment to a firm, attainment of staff set targets, individual value of management, heightened collaboration, staff ingenuity, heightened ambition and vigilance, customer satisfaction and zero employee turnover [1]. Several models abound to justify why viable human resources management determine firm performance. It is unmistakable that viable management effects will be encountered beforehand at the staff level since human management practises seek to guarantee successful people management.

Okoye and Ozejiofor [2] contend that human resources operations should influence employees in the institutions where they are undertaken and, if carried out competently, will guarantee favourable employee outcomes. Favourable yields for the employees culminate in remarkable fiscal as well as structural outcomes. Structural results (operations) are a form of result that is derived from the operating tendency of a body that may consist of top tier remarkable commodities or favourable customer response on client satisfaction development and compensation.

Money can be a major factor in an individual choice of work or performance, but beyond that, other benefits are often more important when it comes to motivating an individual at the workplace such as nonfinancial benefits [3]. Employee output is closely associated to job satisfaction and corresponding support work setting. In addition, employee motivation via financial strategies works best within short timelines, after which motivational drive dies off as workers promptly become accustomed to their obtaining remuneration [1]. This essentially calls for investigation of different non-fiscal gains that highly encourage workers and guarantee outstanding employee efficiency at workplace. In furtherance of this assertion, different 
research have demonstrated that institutions that offered workers non-monetary returns such as wellness programs had encouraged workers contrary to those that failed to adopt such reward systems $[4,5]$.

Wellness programs are vital to employees because workers are kept sound, and more resourceful to the organization since the productivity of the organization is an added advantage over its competitors. The expected advantages of enhanced employee output as a result of good health enhance morale, decrease stress and burnout among workers as well as increase employee output. Taylor and Don, [6] view wellness programs as a method for advancing support of good health instead of Improvement of poor health. They incorporate work out regimes, social exercises recreational chances, spiritual and intellectual advancement programs which thusly impacts on organization main concern where the representatives' wellbeing is seen to enormously influence general productivity [7].

However, the link between wellness programs and employee output might be affected by other factors such as employee workers' union. In the past years, workers unions have been compatible with clamour for increased remunerations and financial forms of staff incentives and appreciation systems for their affiliates. Although this has resulted in some actual benefits more so originating from cash bonuses, the impending economic crisis reduces exertions towards maintained financial impetuses and therefore elicits thought towards execution of wellness program to maintain motivation and in effect employee output [8]. In addition, Murphy [9] opines that workers' union should ensure negotiations or arbitration that are concerned with employees' terms and conditions of employment hence positive social exchange between employees and firm management. Sellers [10] argues that the end result benefit management, employees and workers' unions that act on their behalf for better delivery of set goals through promoting a good cordial relationship and promote membership of its workforce and participation in union activities.

\section{Problem Statement}

Thorne Warren, Wool handler and Himmelstein [11] contends that by growing new and incorporated idea of well-being at workplace can be especially significant since a considerable lot of the ideas have fields such as occupational health administrations, occupational wellbeing and hierarchical consultancy. They have been brought from outside the organizations and have for the most part stayed divided and confined activities which have no genuine connect to day by day exercises of different work places [12].

In Kenya, as a result of several strikes by medical staff, workers union have put more emphasis on pursuit of salary review (monetary benefit) aimed at improving employee output [13]. Nonetheless, there is still a problem of low employee output thus questioning the effectiveness of monetary benefits as the only focused incentive for improving employee output. This calls for the advanced investigation on other alternative incentives such as wellness and how they influence employee's output. Due to increasing economic decline, most organizations are considering the use of nonmonetary benefits that are not valued in monetary terms [14]. This has increased the popularity of the usage of wellness programs. However, there has been little empirical evidence on interaction between wellness program, workers unions' activities and medical Employee output in hospitals. Thus, this study attempted to establish the influence of wellness programs as one of the none monetary benefits on employee output among medical employees at Kenyatta National Hospital (KNH) as moderated by workers' union activities.

\section{RESEARCH HYPOTHESES}

Review of literature on employee wellness programs revealed that wellness programs can improve employee's output. Intellectual wellness programs were indicated to enable employees improve their knowledge and skills which enable them to be effective and efficient while executing their duties at the workplace $[15,16]$. Literature also showed that social wellness programs permit employees to interact with people from different cultures where they share ideas which may be beneficial to their workplace [17 18]. The research further revealed that Physical wellness programs are significant to employees as they keep employees healthy; a healthy employee is an asset to the organization $[19,20]$. However, this studies used wellness as singular variable and failed to enumerate the elements of wellness programs such as sick-offs, flexible schedules, safety and health, medical schemes, injury, compensation, paid holidays, retirement plans and team building and how they affect employee output which the current study sought to investigate. Thus, this study hypothesized that:

$\mathbf{H}_{\mathbf{0 1}}$ : Wellness programs do not statistically significantly influence Medical Employees output at $\mathrm{KNH}$

Workers union activities were shown as important determinants of employee output. Studies conducted showed that perceived effect of workers unions' activities such as negotiations with specific focus on terms and conditions of service and job security of employees contribute greatly to improved job output [21-24]. However, this study did not discuss the role of workers' unions in facilitating negotiations, advocacy, sensitization and arbitration and how these roles moderate the relationship between wellness programs and employee output in Hospital based 
Ruth Kanini Bosire et al., Sch J Econ Bus Manag, Mar, 2021; 8(3): 88-97

working environment. Thus, this study hypothesized that:

$\mathbf{H}_{\text {02: }}$ Workers' Union activities do not moderate the relationship between wellness programs and employee output at $\mathrm{KNH}$

\section{LITERATURE REVIEW Theoretical Review}

This study was anchored on the Herzberg Two-Factor Theory developed by Frederick Herzberg in 1959. This Theory is identified as motivation hygiene theory [25]. Its goal was intended for investigating the level to which one was satisfied or not with their end results. Abrudan and Matei [26] also used applications of Herzberg's two factor theory to reflect on the relationship between what motivates employees and culture of organization. Abrudan and Matei [26] findings showed that motivators come from intrinsic motivation which shows a good outcome to employee output while hygiene factors come from extrinsic elements, which remove dissatisfaction. According to Herzberg [27] good spirits is associated with motivators such as wellness programs

Noble or higher feelings are associated with motivators (wellness programs) while bad or awful feeling are related to hygiene factors (work conditions, job security, salary, peaceful relationship with coworkers, company policy and effective supervision) [27]. Edrak [28] opines that hygiene and motivator factors make an important and positive relation with employee motivation. According to Latham [29], Herzberg two factor theory mostly concentrated on precise requirements for their enjoyment. Ghafoor [30] states that motivators increase the level of motivation whereas decrease in the level of motivation causes the absence of hygiene factors. Herzberg [27] stipulated that fulfilling workers to be encouraged to scale up their production, the administration needs to increase hygiene variables (to avert "Dissatisfaction") encouraging variables of motivation such as wellness programs. Herzberg two factor theories is relevant to this study for putting the worker at fore front of the organization through honoring them as he focused on their wellness unlike others who focused on work goal achievement [31].

\section{Empirical Literature Review}

Richemond and Needham [32] examined the impact of wellness programs on employee job satisfaction in Colleges and Universities. Utilizing a sample of full time or part time college and university faculty members of for-profit and brick and mortar universities in the United States, the results of this correlational study did not predict job satisfaction among employees who participated in wellness programs. In addition, it was found that interaction analysis indicated a relationship between gender and job satisfaction. Females were more likely than males to have higher levels of job satisfaction, as well as years of experience and job satisfaction. Faculty who had employed between 11 and 15 years were more likely to have higher levels of job satisfaction. However, the study was a comparative between male and female on job satisfaction.

In USA, Gobbler, Timothy and Larkin, Ian and Pierce, Lamar [20] examined the effect of a corporate wellbeing program on employee productivity from 111 laborers in five clothing plants. Albeit practically $90 \%$ of organizations use wellbeing programs, existing exploration has concentrated on cost investment funds from protection and truancy. The employee productivity improvement was based on post-program wellbeing changes. Wiped out and sound people who improved their wellbeing expanded profitability by about $10 \%$, with overviews demonstrating sources in improved eating routine and exercise. However, the findings of this study were descriptive statistics only.

Kasenga et al. [33] conducted a study on staff motivation and welfare in Adventist health facilities in Malawi, a qualitative research study by group discussion with health care workers and supportive staff. Findings concluded that Adventist health facilities need to be revised; they must increase the communication between management and the health care staff through schedule routine meetings.

Kemboi, Biwott, Tarus and Keter [34] carried out a study on employee Welfare among Civil Servants in Nandi County using exploratory research design. Stratified and random sampling to select 350 representatives of Nandi County. The study revealed that wellbeing and, Retirement designs and Flexible Schedules at Workplace had critical impact on Service delivery, consequently the need to address staff welfare issues.

Ngeno and Muathe [15] undertook a literature review on employee wellbeing programs in Kenya using a case study design. Information was gathered through semi-structured interviews, focus groups and direct observation. The study revealed a conflicting view on advantages exceeding the costs required with glaring decrease of costs; restricted sickness related absenteeism increased productivity and better quality of life.

Tuwai, Kamau and Kuria [16] did a study on the effect of Corporate Wellbeing Practices on Employees' Performance among Commercial Banks in Kenya using 43 business banks with a focus on HR Heads. Both structured and unstructured questionnaire instrument were used to collect data which was analysed using qualitative technique and descriptive method. The study revealed that budgetary and physical wellbeing programs enhanced employee output by enhancing their wellbeing and expanding their 
Ruth Kanini Bosire et al., Sch J Econ Bus Manag, Mar, 2021; 8(3): 88-97

productivity by $11 \%$. Generally, the study proposes that organizations can increment operational productivity through socially firm wellbeing policies that enhance the workers' health and economic value. However, the study used targeted HODs whose opinion is likely to be biased; the current study targets all medical staff.

Kihoro, Mungania and Kiganjo [35] did a study on the effect of wellness programs on organizational performance in the banking industry in Kenya. A cross sectional survey was employed using a sample of 44 registered commercial banks by the Central Bank of Kenya. Data was collected using structured questionnaire. Data was analyzed using Descriptive statistics (mean, standard deviation and percentages) and inferential statistics (Pearson correlation and multiple regressions). The outcomes indicated that wellness program impacted the performance of the organization through preventive care, education and teaching the importance of the wellness program through a good team leader. The investigation suggests that organizations should concentrate on the utilization of wellness programs rehearses as they are basic to guarantee that organizations assist in attaining their goals. This study however, concentrated much on organization performance while this study looks at employee performance.

Mungania [36] conducted a study on work life balance on employee output of the banking industry, Kenya, using both quantitative and qualitative approaches. The study confirmed that flexible work arrangements, wellness programs, family responsibility concerns were more strongly related to performance of the banking industry in Kenya. It also found that institutions that support employees in work life balance practices had higher performance. The study established the importance of flexible work arrangements, wellness programs and family responsibility concerns though the findings are too general. Nevertheless, the study content scope was limited to work life balance which is a dimension of wellness program.

Sisson [37] did a study of the attitudes and approaches to direct participation of the social partners throughout Europe, involving around 200 interviews with senior representatives of the peak employers' and trade union organisations in two main sectors, engineering and banking. The study found that flexible working practices were as unequivocally correlated with autonomous representation by unions and work councils similarly as with foreign competition for an organisation's products. However, this study did not provide a direct link on employee performance and data was collected only from workers representatives.

Osman [24] carried out a study on the Effect of Union Activities on Employee's Performance: A Case Study at the Bawku Presbytarian Hospital in Saudi. The study targeted 70 specialists' respondents from the Bawku Presbyterian clinic who were individuals from Health Service Workers Union. 64\% of the wellbeing laborers said worker's organizations help laborers to get their requests. The discoveries of this investigation support that union activities have impact on laborers performance at the work environment. The study used workers union as independent variable while the current study used workers union activities as moderating variable

Mwanyenza [38] examined the role of trade unions in solving employee's problems at Mwanza City Council. Simple random and purposive sampling techniques were used to get a total of 75 study respondents from distinct trade unions which are C.W.T, TUGHE, and TALGWU. Data was gathered via surveys, documentary reviews and questionnaires. Data analysis was contingent on qualitative evaluation which is endorsed by qualitative analysis presented in forms of charts, percentages and tables. The findings of this research elaborated that trade unions have not carried out their part in guaranteeing that workers issues and complain are settled and their rights are honoured. The research showed that if staff issues could be settled, there would be better working condition as such it will reinforce job satisfaction and employee output. Hence, dire performance by trade unions culminates in employee dissatisfaction causing high rates of nonattendance and employee turnover. This study was purely qualitative.

Anyango [39] did a study on factors affecting the performance of trade union in Kenya at Nyando district, Kisumu County. The researcher used Descriptive method which showed different outcomes on how the trade union performed when there was no good communication between union and members, negotiation on salary increment and strike. Due to lack of communication between the trade union and their members, it resulted to low work performance.

Jepkorir [40] conducted a study on the effect of trade union on organizational productivity in the cement manufacturing industries in Nairobi. Descriptive Statistics was used to analyze the data and there were different outcomes that showed strikes were the main means for the union to express themselves when conciliation failed. The two studies used descriptive statistics only to analyze data and did not show a relationship between trade union activities and employee performance.

\section{MATERIAL AND METHODS Research Design}

An explanatory research design was employed to establish the causal relationship between the independent variable (Wellness programs) and the dependent variable (Employee Output). The explanations argued whether phenomenon Y (Employee 
Ruth Kanini Bosire et al., Sch J Econ Bus Manag, Mar, 2021; 8(3): 88-97

output) is affected by variable $\mathrm{X}$ (wellness program) as moderated by workers union activities and strove to show the extent of the effect.

\section{Sampling Techniques and Sample Size}

This study was conducted at Kenyatta National Hospital, located in Nairobi County, Kenya. The study sampling frame was a list of 2175 medical staff distributed across13 worker categories (Doctors $=153$, Nursing Staff $=1555$, Dental Officers $=19$, Pharmacists $=19$, Clinical Officers $=62$, Radiographers $=45$, Public Health Officers $=20$, Physiotherapists=61, Occupational Therapists $=33$, Orthopaedic technologists =29, Dental Technician $=12$, Theatre assistants $=74$, Health Information=93). The sample size of 328 was determined using Cochran [41] formula modified by Hitesh [42]. The study used Simple random sampling to select respondents that were representative of the entire KNH Medical workforce.

\section{Data Collection Instruments}

This study employed questionnaires as instrument for capturing data that were used to analyze the study objectives. The researcher employed closed ended questions using 1-5 likert type statements to collect data. The closed ended questions had a high response rate and uniformity of responses. The questionnaire had closed ended questions and comprised of six sections covering the key issues pertinent to this study, including: basic demographic data (section A); Employee Recognition practices(section B); Employee Training and Development Practices (section C); Employee Wellness Practices (section D); Employee Output (section E); Workers Unions (section F). A questionnaire allowed greater uniformity in the way questions were asked ensuring greater comparability. In addition, questionnaires have the advantage of collecting information from various people simultaneously [43].
Validity and Reliability of Research Instruments

The Content Validity Index (CVI) was used to quantify the content validity. Findings from table 1 showed that CVI was above .6 as recommended by Ayre, Colin \& Scally, Andrew [44] hence retained for further analysis. In addition, construct validity was ensured by deriving the dimensions of employee output, wellness and workers union representatives from existing literature which were assessed through use of exploratory factor analysis using Kaiser-Meyer-Olkin estimate of sampling adequacy, Bartlett's test of sphericity and varimax rotations components. Prior to performing PCA, the suitability of data for factor analysis was assessed. Factors with factor loadings of above 0.3 were retained for further data analysis. All items met this criterion and therefore items were retained for further analysis. The Kaiser-Meyer-Olkin Measure value exceeded the recommended value of 0.6 [45] and Bartlett's Test of Sphericity [46] was significant with $\mathrm{p}$ value less than 0.000 . Principal components analysis revealed the presence of two components with eigen values exceeding 1, explaining $63.16 \%, 65.74 \%$ and $67.75 \%$ of the employee output, wellness programs and workers union activities variance respectively.

Further, In order to determine the internal consistency of the data collection tool an assessment was undertaken using Cronbach's alpha value attributed to Cronbach [47], also known as the reliability coefficient to determine the internal consistency/ reliability of the Likert-type scales used in the research instrument. From the results generated, the Cronbach alpha for each variable based on the average of interitem correlation was above .70. Thus, the results met the required threshold for further analysis as documented in the subsequent sections of this article.

Table-1: Validity and reliability of Research Instruments

\begin{tabular}{|l|l|l|l|l|l|l|l|}
\hline \multicolumn{9}{|c|}{ Exploratory Factor Analysis } \\
\hline & Items & KMO & $\begin{array}{l}\text { Bartlett's } \\
\text { Test }\end{array}$ & Loadings & \% CV & CVI & $\begin{array}{l}\text { Cronbach's Alpha Based } \\
\text { On Standardized Items }\end{array}$ \\
\hline Employee output & 16 & 0.92 & $3399.19^{*}$ & $>0.5$ & 63.16 & 0.60 & 0.949 \\
\hline Wellness program & 13 & 0.89 & $2441.70^{*}$ & $>0.5$ & 65.74 & 1.00 & 0.931 \\
\hline Worker union activities & 15 & 0.91 & $3537.49^{*}$ & $>0.5$ & 67.75 & 0.80 & 0.948 \\
\hline
\end{tabular}

\section{Data Analysis and Presentation}

Inferential statistics was analyzed using correlation and regression analysis. Variables were transformed to interval data variables to serve as regressors / independent variable influencing the medical employee output. To determine how independent variable influences medical employee output, the study regressed transformed variable on employee output. The statistical significance of each of the regression equations above were tested using the ANOVA test which check for goodness of fit. In line with the recommendations of Baron and Kenny [48] and Hayes [12], Hierarchical multiple regression analysis was used to test the moderating effect of worker union activities on wellness programs and employee output at KNH.

\section{DATA ANALYSIS, PRESENTATION AND DISCUSSIONS Descriptive Statistics}

The study adopted an 'average score approach' to compute participants' overall score [49]. Table 4.1 shows the results on data transformation. From the findings, employee output had the highest mean (3.78) 
Ruth Kanini Bosire et al., Sch J Econ Bus Manag, Mar, 2021; 8(3): 88-97

followed by wellness program (3.37) and worker union activities (mean $=3.37$ ). The standard deviations for the variables were less than 1 except employee output indicating less variation in the responses. Finally, the independent variable and the dependent variable were normally distributed with kurkosis and Skewness less than \pm 1.98 .

Table-4.1: Data Transformation

\begin{tabular}{|l|l|l|l|l|l|l|}
\hline $\mathrm{n}=267$ & Min & Max & Mean & Std. Deviation & Skewness & Kurtosis \\
\hline Employee output & 1.00 & 5.00 & 3.78 & 0.79 & -0.94 & 1.45 \\
\hline Wellness program & 1.00 & 5.00 & 3.37 & 0.99 & -0.28 & -0.51 \\
\hline Workers union activities & 1.07 & 5.00 & 3.37 & 0.86 & -0.23 & -0.20 \\
\hline
\end{tabular}

Source: Field Data, (2020)

\section{Inferential statistics}

Before running the regression analysis, the researcher run the correlation matrix in order to check whether there was a relationship between variables. The results also showed that there was a significant positive relationship between wellness programs and employee output at $\mathrm{KNH}(\mathrm{r}=.796, \mathrm{p}<.01)$. This implies that an increase in wellness programs improved the employee output at KNH. The study findings also showed that there was a significant positive relationship between the workers union activities and the employee output at $\mathrm{KNH}(\mathrm{r}=.547, \mathrm{p}<.01)$. This implies that workers union activities increases employee output at $\mathrm{KNH}$.

Table-4.2: Correlation

\begin{tabular}{|l|l|l|l|}
\hline & Employee output & Wellness program & Workers union activities \\
\hline Employee output (EO) & 1 & & \\
\hline Wellness program (WP) & $.796^{* *}$ & 1 & \\
\hline Workers union activities (WUA) & $.547^{* *}$ & $.645^{* *}$ & 1 \\
\hline$* *$ Correlation is significant at the 0.01 level (2-tailed). \\
\hline
\end{tabular}

\section{Testing of Hypotheses}

Linear regression for testing the direct effect of the wellness program on employee output were performed to test the model fit and to establish the predictive power of the study models. The findings are presented on table 4.3 below. Results revealed that 63.4 percent variation on employee output could be explained by wellness programs in $\mathrm{KNH}\left(\mathrm{R}^{2}=.63 .4\right)$. The ANOVA model showed model fitness for effect of wellness programs on employee output was statistically significant $(\mathrm{F}=459.780, \rho=.000)$. Thus, the model was fit to predict employee output using wellness programs.

Hypothesis $1\left(\mathrm{H}_{\mathrm{o} 1}\right)$ postulated that there is no statistically significant influence of wellness programs on medical employee output at KNH. Findings showed that wellness programs had coefficients of estimate which was significant basing on $\beta_{1}=0.796(\mathrm{p}$-value $=$ 0.000 which is less than $\alpha=0.05$ ) implying that the null hypothesis was rejected and it was therefore concluded that wellness programs have significant effect on medical employees' output.

Table-4.4: Linear Regression for wellness Programs and Employee Output

\begin{tabular}{|l|l|l|l|l|l|}
\hline \multicolumn{2}{|l|l|}{ Unstandardized Coefficients } & \multicolumn{2}{l|}{ Standardized Coefficients } \\
\hline & B & Std. Error & Beta & T & Sig. \\
\hline (Constant) & 1.622 & 0.105 & & 15.475 & 0.000 \\
\hline Wellness program & 0.639 & 0.030 & 0.796 & 21.442 & 0.000 \\
\hline Summary Statistics & 0.796 & & & & \\
\hline R & 0.634 & & & & \\
\hline R Square & & & & \\
\hline Adjusted R Square & 0.633 & & & & \\
\hline ANOVA (F stat) & 459.780 & & & & \\
\hline ANOVA (F prob) & 0.000 & & & & \\
\hline b Dependent Variable: employee output & & & \\
\hline
\end{tabular}

Based on the above results the study derived the following simple linear regression model as shown below.
The model shows that increase of wellness programs by a unit increase employee output by 0.639 units. The study findings in table 4.5 indicate the regression results for the moderating effect of workers union activities on the relationship between wellness programs and employee output at $\mathrm{KNH}$

$$
Y=1.622+0.639 X_{1}+\varepsilon
$$


Ruth Kanini Bosire et al., Sch J Econ Bus Manag, Mar, 2021; 8(3): 88-97

$\mathbf{H}_{\mathbf{0 2}}$ stated that workers' union activities do not moderate the relationship between wellness programs and employee output. However, the regression results showed that workers; union activities positively moderated the relationship between wellness programs and employee output, by $14 \%$. This suggests that workers' union activities facilitate the relationship between wellness programs and employee output. The ANOVA findings showed that wellness program and workers union activities were statistically significant (F $=131.95, \rho=.000)$. Thus, the model was fit to predict the moderation of workers union activities between wellness and employee output. The model shows that increase of wellness program moderated by workers' union activities by a unit increase employee output by .65 units respectively. The findings showed that workers' union activities do moderate the link between wellness programs and employee output. The implication is that workers' union activities are key in ensuring that the hospital fully implements employee wellness programs. With the focus on employee wellness programs, there is an improvement in employee productivity. Based on the above results the study derived the following simple linear regression model as shown below.

$$
\mathrm{Y}=1.600+0.074 \mathrm{WP} * \mathrm{WUA}+\varepsilon
$$

Table-4.5: Hierarchical Regression for Wellness Programs, Workers Union Activities and Employee Output

\begin{tabular}{|l|l|l|l|l|l|}
\hline \multicolumn{2}{|l|}{ Unstandardized Coefficients } & Standardized Coefficients & t & Sig. \\
\hline \multicolumn{2}{|l|}{ B } & Std. Error & Beta & & \\
\hline (Constant) & -0.01 & 0.04 & & -0.26 & 0.79 \\
\hline Z score (wellness program) & 0.77 & 0.04 & 0.77 & 19.73 & 0.00 \\
\hline (Constant) & 0.01 & 0.03 & & 0.26 & 0.80 \\
\hline Z score (wellness program) & 0.24 & 0.06 & 0.65 & 4.19 & 0.00 \\
\hline Z score (WP*WUA) & 0.64 & 0.06 & & 11.49 & 0.00 \\
\hline Summary statistics & & & & \\
\hline R & 0.77 & 0.85 & & & \\
\hline R Square & 0.60 & 0.73 & & & \\
\hline Adjusted R Square & 0.59 & 0.73 & & & \\
\hline Std. Error of the Estimate & 0.64 & 0.52 & & & \\
\hline Change Statistics & 0.60 & 0.14 & & & \\
\hline R Square Change & 389.28 & 131.95 & & & \\
\hline F Statistic & 1 & 1 & & & \\
\hline df1 & 265 & 264 & & & \\
\hline df2 & 0.000 & 0.000 & & & \\
\hline Sig. F Change & & & & \\
\hline a Dependent Variable: Employee output & & & & \\
\hline
\end{tabular}

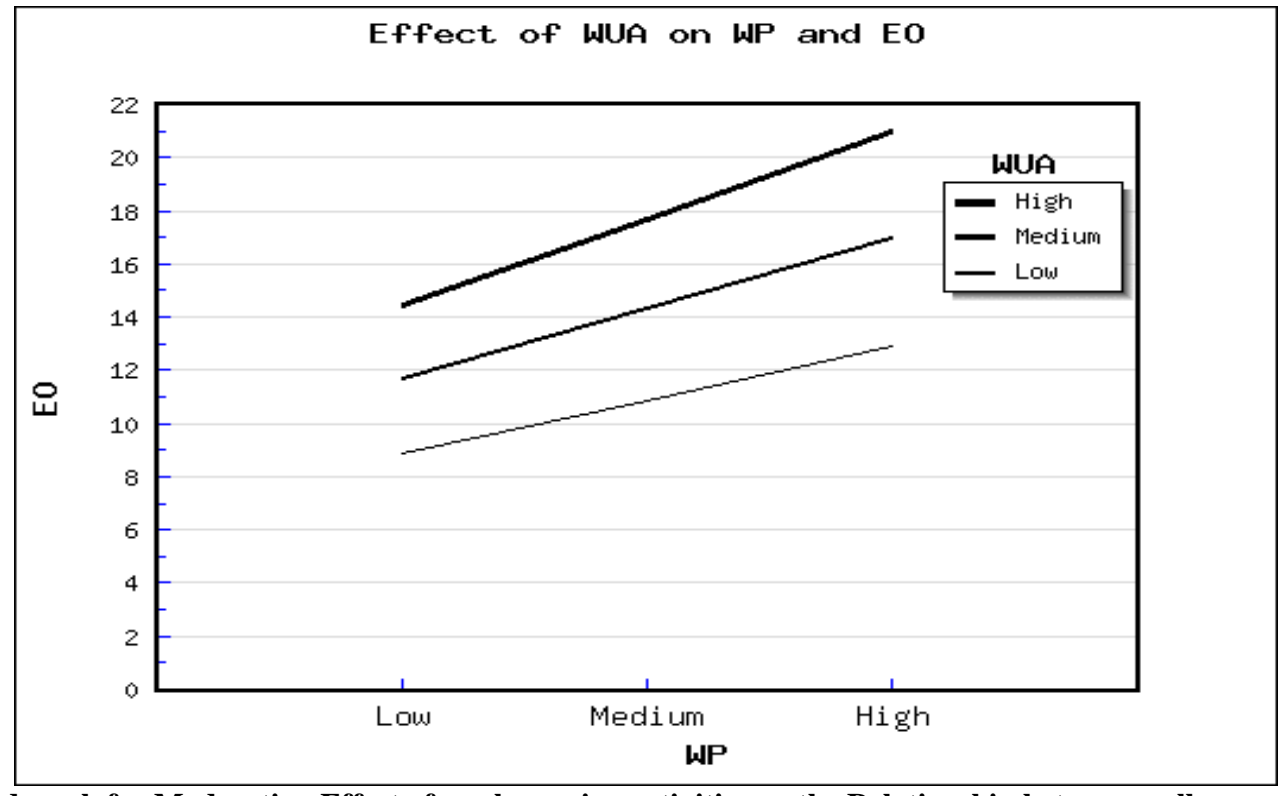

Fig-4.1: Modgraph for Moderating Effect of worker union activities on the Relationship between wellness programs and employee output

Key: WP=Wellness Program, WUA=workers union activities, EO=employee output Source; (Field data, 2020) 
The interaction plot in Figure 4.1 displays an enhancing effect that as workers' union activities increases, the effect of wellness programs on employee output increases as well, as depicted by the steepness of the slope. Hypothesis 2 was therefore rejected and the alternative hypothesis therefore upheld thus, workers' union activities positively and significantly moderate the relationship between wellness programs and employee output.

\section{Discussion of the Findings}

Wellness Program statistically and significantly influences medical employee output at $\mathrm{KNH}$. The findings are also in tally with that of Tuwai, Kamau and Kuria [16] which concluded that budgetary and physical wellbeing programs enhance employee output. Consistent with the results, Gubler, Larkin and Pierce [50] contended that productivity can arise from wellbeing programs which increase motivation and employee ability to take activities that enhance wellbeing. In a similar vein, Kemboi, Biwott, Tarus and Keter [34] concluded that wellbeing and, retirement designs and flexible schedules at workplace had critical impact on service delivery. Besides, Mungania [36] stipulated that flexible work arrangements and wellness programs contribute to employee productivity. Overall, employee wellness programs bring about an improvement in employee output. The study has therefore added sufficient insights on the nexus between employee wellness programs and their output. This is especially because there is limited literature on the relationship between wellness programs and employee output as moderated by workers' union workers in hospitals.

Findings of the moderated hierarchical regression indicated that worker union activities positively moderated the relationship between wellness programs and employee output. Worker union activities have contributed to the success of employee wellness programs which have in turn led to improved employee output. As such, efforts towards ensuring that employees are treated well and have good working conditions results in improved productivity among the employees. In line with the results, Sisson [37] found that flexible working practices were as unequivocally correlated with autonomous representation by unions and work councils. Further support to the study findings is by Voos [51] who alluded that organizations whose workers' unions participate in implementation of employee benefit programs improve employee output while those whose union leaders are not involved have no improvement. Similarly, Gyesie [52] established that workers unions have a significant impact on salaries, job benefits, wage parity amongst their members, job security and protections.

\section{CONCLUSION AND RECOMMENDATIONS Conclusion}

The hospital has been able to increment employee output through employee wellness programs. This has been mainly been attributed to the fact that the medical personnel are granted sick offs and their health and safety are given a top priority. In so doing, there is increased commitment and loyalty of employees. Despite this, the hospital has not fully implemented the wellness programs. Gaps still exist in the medical scheme, retirement plans and the hospital's compensation policies. As such, employees' output could be increased further through more emphasis on wellness programs. Moreover, as per the study results workers union advocating for policies and legislation toward proper and effective employees' working conditions, and health and safety encourages employees to achieve all the goals in good time and give top attention to top priorities and deliver all daily allocated tasks.

\section{Theoretical Implication}

The theoretical implication of this study is that it supports Herzberg contrived two-factor theory as it validated Herzberg contrived two-factor theory of motivation. According to Herzberg, in order for employees to be motivated, both factors, that is motivational and hygiene factors have to be fulfilled. This study supports the theory by providing empirical evidence of wellness programs as motivations and hygiene factor which enhances employee output in hospitals. The study has also contributed to the theory by giving specific aspect of wellness programs that motivate employees and improve individual output at the hospital.

\section{Recommendation for Policy and Managerial Practice}

Finally, to sustain employee output, hospitals need to fully embrace employee wellness programs due to its benefits to the human resource pool. Specifically, the hospital needs to ensure that employees' safety and health are adequately provided for in the hospital's policy manuals. As well, the hospital should make it a priority to raise awareness on health and safety matters among the employees. Further, the employees' wellness programs should be designed in such a way that it caters for sick off, employees paid holidays, medical scheme and retirement plans for the employees. The resulting outcome would be an improvement in employee wellbeing and their productivity at the workplace.

\section{Limitation of the Study}

The results of the study may not be generalized to all sectors owing to particularities of different sectors. Therefore, future research be conducted in different sectors and more so a comparative study between sectors is recommended. The study focused 
Ruth Kanini Bosire et al., Sch J Econ Bus Manag, Mar, 2021; 8(3): 88-97

only on employees of Kenyatta National Hospital which is a parastatal. It is possible that if the study was conducted on other medical personnel of the private sector, the magnitude and direction of the relationship between the study variables might be different. Thus, future research should include the private sector or similar study across heterogeneous industries to better understand the relationship between non-monetary benefits and employee output.

\section{REFERENCES}

1. Herranz-Zarzoso N, Sabater-Grande G. Monetary incentives and self-chosen goals in academic performance: An experimental study. International Review of Economics Education. 2018 Jan 1;27:34-44.

2. Okoye PV, Ezejiofor RA. The effect of human resources development on organizational productivity. International Journal of Academic Research in Business and Social Sciences. 2013 Oct 1;3(10):250.

3. Whetten DA and Cameron KS. Developing Management Skills. Upper Saddle River, New Jersey Pearson Prentice Hall. 2016.

4. Orwa BH. A Research on Labour Turnover in sugar industry in Kenya: European Journal of Business Management.

5. Kiilu CN. Employee Motivation at Kenya Polytechnic. Unpublished MBA Project.University of Nairobi; 2010.

6. Taylor S and Don M. Financial Planning (4th ed.). College Press. USA: Boston; 2010.

7. Naydeck BL, Pearson JA, Ozminkowski RJ, Day BT, Goetzel RZ. The impact of the highmark employee wellness programs on 4-year healthcare costs. Journal of occupational and environmental medicine. 2008 Feb 1;50(2):146-56.

8. Thuita G, Oiye Y. Compensation, Working Conditions And Employee Satisfaction In Kilifi Export Processing Zones, Kenya. International Journal of Economics, Business and Management Research. 2018;2(2):266-76.

9. Murphy C. Fear and leadership in union organizing campaigns: An examination of workplace activist behavior. SAGE Open. 2016 Jan 20;6(1):2158244015623932.

10. Sellers JP. The UK living wage: A trade union perspective. Employee Relations. 2017; 39(6): 790799.

11. Himmelstein DU, Thorne D, Warren E, Woolhandler S. Medical bankruptcy in the United States, 2007: results of a national study. The American journal of medicine. 2009 Aug 1;122(8):741-6.

12. Hayes AF. Introduction to mediation, moderation, and conditional process analysis: A regressionbased approach. New York: Guilford Press; 2012.

13. Kaguthi GK, Nduba V, Adam MB. The impact of the nurses', doctors' and clinical officer strikes on mortality in four health facilities in Kenya. BMC Health Services Research. 2020 Dec;20:1-0.

14. Kappel M. What is bonus pay?. 2018. Retrieved on the January $8^{\text {th }} \quad 2019$, from https://www.patriotsoftware.com/payroll/training/b $\log$ /what-is-bonus-pay.

15. Ngeno WK, Muathe SM. Critical review of literature on employee wellness programs in Kenya. International Journal of Research in Social Sciences. 2014 Dec;4(8):32-41.

16. Tuwai BB, Kamau C, Kuria S. Effect of corporate wellbeing practices on employees' performance among commercial banks in Kenya. International Journal of Scientific and Research Publications. 2015 May;5:1-6.

17. Wollseiffen P, Ghadiri A, Scholz A, Strüder HK, Herpers R, Peters T, Schneider S. Short bouts of intensive exercise during the workday have a positive effect on neuro- cognitive performance. Stress and Health. 2016 Dec;32(5):514-23.

18. Xiu L, Dauner KN, McIntosh CR. The impact of organizational support for employees' health on organizational commitment, intent to remain and job performance. InEvidence-based HRM: a Global Forum for Empirical Scholarship 2019 Dec 2. Emerald Publishing Limited.

19. McManus IC, Jonvik H, Richards P, Paice E. Vocation and avocation: leisure activities correlate with professional engagement, but not burnout, in a cross-sectional survey of UK doctors. BMC medicine. 2011 Dec;9(1):1-8.

20. Gubler T, Larkin I, Pierce L. Doing well by making well: The impact of corporate wellness programs on employee productivity. Management Science. 2018 Nov;64(11):4967-87.

21. Gichaba SM. Perceived influence of trade unions on terms and conditions of service and job security of employees at Kisii University-Kenya (Doctoral dissertation, University of Nairobi).

22. Ibrahim IM. Impact of trade union on improving employees working conditions: The case study of COTWU and TUGHE (Doctoral dissertation, The Open University of Tanzania).

23. Bryson A, Barth E, Dale-Olsen H. Union Density, Productivity, and Wages. National Institute of Economic and Social Research; 2017 Aug.

24. Chilala O. The Effect of Union Activities on Employee's Performance: A Case Study at the Bawku Presbytarian Hospital. Available at SSRN 2551452. 2015.

25. Tan TH, Waheed A. Herzberg's motivation-hygiene theory and job satisfaction in the Malaysian retail sector: The mediating effect of love of money.

26. Matei MC, Abrudan MM. Adapting Herzberg's two factor theory to the cultural context of Romania. Procedia-Social and Behavioral Sciences. 2016 Jun 7;221:95-104.

27. Herzberg F. One more time: How do you motivate employees: Harvard Business Review Boston. 1968. 
Ruth Kanini Bosire et al., Sch J Econ Bus Manag, Mar, 2021; 8(3): 88-97

28. Edrak BB, Yin-Fah BC, Gharleghi B, Seng TK. The effectiveness of intrinsic and extrinsic motivations: A study of Malaysian Amway company's direct sales forces. International Journal of Business and Social Science. 2013 Aug 1;4(9):96-103.

29. Latham GP. Work Motivation: History, Theory, Research, and Practice. Sage Publications Inc. 2012; 337.

30. Ghafoor MM. Role of demographic characteristics on job satisfaction. Far East Research Centre. 2012; 6(1), 30-45

31. Lambrou P, Kontodimopoulos N, Niakas D. Motivation and job satisfaction among medical and nursing staff in a Cyprus public general hospital. Human resources for health. 2010 Dec;8(1):1-9.

32. Richemond DJ, Needham C. The Impact of Wellness Programs on Employee Job Satisfaction in Colleges and Universities. Open Journal of Business and Management. 2020 Mar 2;8(02):569.

33. Kasenga F, Hurtig AK. Staff motivation and welfare in Adventist health facilities in Malawi: a qualitative study. BMC health services research. 2014 Dec;14(1):1-9.

34. Kemboi A, Biwott KG, Tarus KT and Keter CJ. Staff Welfare as an Antecedent to Service Delivery among Civil Servants in Kenya a Case Study of Nandi County. European Journal of Business and Management. 2013; 5(22)

35. Kihoro JM, Mungania AK and Waiganjo EW. Influence of Flexible Work Arrangement on Organizational Performance in the Banking Industry in Kenya. The International Journal of Academic Research in Business and Social Sciences. 2016; 6: 159-172.

36. Mungania AK. Influence of work life balance practices on performance of the Banking Industry in Kenya. Unpublished thesis for the award of Degree of Doctor of Philosophy in Human Resource Management in the Jomo Kenyatta University of Agriculture and Technology; 2017.

37. Sisson K. Closing the Gap: Direct Participation in Organizational Change, Dublin: European Foundation for the Improvement of Living and Working Conditions; 2015.

38. Mwanyenza L. Examining the role of trade unions in solving employee's problems. Open university of Tanzania. Dar es salaam, Tanzania; 2015.

39. Anyango C, Obange N, Abeka E, Ondiek GO, Odera $\mathrm{O}$ and Ayug ME. Factor affecting performance of trade union in Kenya. America Journal of business and management. Oklahoma City USA. 2013; 2(2): 181- 185.

40. Jepkorir BM. "The Effect of Trade Unions on Organizational Productivity in the Cement Manufacturing Industry in Nairobi," School of Business, University of Nairobi.2014.

41. Cochran WG. Sampling Techniques, 2nd Ed., New York: John Wiley and Sons, Inc.1963.

42. Hitesh S. How to calculate sample size in an animal study, Natl. J. Physiol. Pharmacol. 2011; 1(1),35 -39

43. Patton, M. Qualitative Research and Evaluation Methods, 3rd edn. Thousand Oaks, CA: Sage.2002.

44. Ayre C, Scally AJ. Critical values for Lawshe's content validity ratio: revisiting the original methods of calculation. Measurement and Evaluation in Counseling and Development. 2014 Jan;47(1):79-86.

45. Kaiser HF. A second generation little jiffy. Psychometrika. 1970 Dec 1;35(4):401-15.

46. Bartlett MS. A note on the multiplying factors for various $\chi 2$ approximations. Journal of the Royal Statistical Society: Series B (Methodological). 1954 Jul;16(2):296-8.

47. Cronbach LJ. Coefficient alpha and the internal structure of tests. psychometrika. 1951 Sep;16(3):297-334.

48. Baron RM, Kenny DA. The moderator-mediator variable distinction in social psychological research: Conceptual, strategic, and statistical considerations. Journal of personality and social psychology. 1986 Dec;51(6):1173.

49. Osborne J. Improving your data transformations: Applying the Box-Cox transformation. Practical Assessment, Research, and Evaluation. 2010;15(1):12.

50. Gubler T, Larkin I, Pierce L. Motivational spillovers from awards: Crowding out in a multitasking environment. Organization Science. 2016 Apr;27(2):286-303.

51. Voos PB. Managerial perceptions of the economic impact of labor relations programs. ILR Review. 1987 Jan;40(2):195-208.

52. Gyesie N. Exploring the Impact of Collective Bargaining Agreements on Employee Performance Management in U.S.A. Unpublished dissertation for the award of Degree of Doctor of Philosophy Management Walden University; 2017. 